\title{
CAPACITY BUILDING IN HIGHER EDUCATION Resilience Improvement in Balkan Region
}

\author{
Mirjana Laban ${ }^{\mathrm{a}}$, Srđan $_{\text {Popov }^{\mathrm{a}}, \text { Vlastimir Radonjanin }^{\mathrm{a}} \text {, Verica Milanko }}^{\mathrm{b}}$, Ana Frank ${ }^{\mathrm{a}}$, \\ Vukoslavčević Suzana ${ }^{a}$ \\ ${ }^{a}$ University of Novi Sad, Faculty of Technical Sciences, Department for Civil Engineering and Geodesy, Novi Sad, \\ Serbia \\ ${ }^{\mathrm{b}}$ Higher Education Technical School of Proffesional Studies, Školska 1, Novi Sad, Serbia
}

\begin{abstract}
In order to improve the resilience of the region to hazards, it is necessary to provide the required number of experts that is to modernize and develop higher education at the regional higher education institutions in the field of Disaster Risk Management and Fire Safety Engineering. A master study program should be developed to satisfy various criteria, according to regional needs for resilient society, such as the shift from reactive to proactive actions, developing a culture of prevention in built environment and learning to live with risks. Final goal is to produce capable experts, to be able to withstand difficult requirements of today and tomorrow. Compliance of the regional master program with similar programs, developed in the EU countries, strengthens the capacity of individual countries and the region as a whole in the process of European integration.
\end{abstract}

Keywords: resilient, higher education, disaster risk management, fire safety engineering, Balkans

\section{INTRODUCTION}

Natural disasters - floods, landslides, earthquakes, storm winds, hail, drought, as well as wild fires and building fires are on the rise in the last decades in the Balkans. Numerous human casualties, extensive damages to urban areas, negative impact on the natural environment and further weakness of the regional economy are indicators of increasing vulnerability. Preliminary surveys have shown that the knowledge of the vast majority of existing staff in this area (state administration, public institutions and companies) is based on the education acquired from other engineering disciplines with different levels of knowledge, and from the skills and experiences that were gained in practice. Those competences, knowledge and skills are insufficient to solve the increasing number of problems in the field of Disaster Risk Management and Fire Safety Engineering. Moreover, the lack of safety culture in society in general is also notable.

Decision No 1313/2013/EU on a Union Civil Protection Mechanism, in view of the significant increase in the numbers and severity of natural and man-made disasters in recent years and in a situation where future disasters will be more extreme and more complex, with far-reaching and longer-term consequences as a result, in particular, of climate change and the potential interaction between several natural and technological hazards, emphasize an integrated approach to disaster management as increasingly important. Prevention is of key importance for protection against disasters and requires further action, as called for in the European Parliament Resolution (2010) entitled a "Community approach on the prevention of natural and manmade disasters". To reach the prevention objectives and carry out prevention actions, improving the disaster risk knowledge base and facilitate the sharing of knowledge, best practices and information, was defined as the first ranged action to take. Education and training (ET 2020) lie at the heart of the Europe 2020 strategy to exit the recession and establish the foundations for future knowledge-based growth and social cohesion. The same goal is promoted in multiple EU documents, e.g.: European and Mediterranean Major Hazards Agreement (EUR-OPA), South East Europe 2020 Strategy - Jobs and Prosperity in 
the European Perspective (SEE 2020 Strategy) and Supporting growth and jobs - an agenda for the modernization of Europe's higher education systems COM(2011) 567 final.

All above listed are common objectives and goals both for EU and Balkan region, considering the on-going European integration process in the Balkans. The resilience improvement by developing higher education is also in compliance with Balkan countries' national higher education strategies and action plans, as well as national strategies in the field of fire protection and emergency situation.

The brief analysis of available bachelor, master and doctoral study programs in the field of Disaster Risk Management and Fire Safety Engineering was done on the regional and European level (Laban et al. 2015). There is an insufficient number of study programs, and the number of graduates is not sufficient for regional/national needs.

Climate change, fast urbanization and new technologies, in interaction with irresponsible human activities, cause the need for multidisciplinary and interdisciplinary engineering competences, knowledge and skills. Considering these, available higher education is insufficient and unsustainable at regional level without modernizing and further development.

\section{AVALABLE STUDY DRM \& FSE PROGRAMS IN BALKAN REGION}

The survey of available study programs in the field of Disaster Risk Management and Fire Safety Engineering was done based on latest information about accredited study programs on Ministries of higher education web-sites (Laban et al. 2015). In Serbia and Croatia, 17 study programs were found (Table 1). Among those, there is only one $1^{\text {st }}$ level - bachelor academic study program and three on the $2^{\text {nd }}$ level - master of academic studies. Regarding the professional studies, there are 7 bachelors and 6 specialist study programs or modules.

Table 1: The results of available DRM\&FSE study programs survey (Croatia and Serbia)

\begin{tabular}{|c|c|c|c|}
\hline No & $\begin{array}{l}\text { Country, City, } \\
\text { Higher Education Institution }\end{array}$ & Bologna $1^{\text {st }}$ level study program & Bologna $2^{\text {nd }}$ level study program \\
\hline 1 & $\begin{array}{c}\text { Croatia, Zagreb } \\
\text { College of Occupational Safety and } \\
\text { Health, http://www.vss.hr/ }\end{array}$ & $\begin{array}{l}\text { Professional studies of Safety, } \\
\text { module - Fire Protection, } \\
\text { Bachelor, (180 ETCS) }\end{array}$ & $\begin{array}{c}\text { Professional studies of Safety, module } \\
\text { - Fire Protection, } \\
\text { Specialist, (120 ETCS) }\end{array}$ \\
\hline 2 & $\begin{array}{c}\text { Croatia, Karlovac, } \\
\text { University of Applied Sciences, } \\
\text { http://www.vuka.hr/ }\end{array}$ & $\begin{array}{c}\text { Professional studies Safety and } \\
\text { Protection, module - Fire Protection } \\
\text { Bachelor, (180 ETCS) }\end{array}$ & $\begin{array}{l}\text { Professional studies Safety and } \\
\text { Protection, } \\
\text { module - Fire Protection, } \\
\text { Specialist, (120 ETCS) }\end{array}$ \\
\hline 3 & $\begin{array}{c}\text { Croatia, Rijeka, } \\
\text { Polytechnic of Rijeka, } \\
\text { http://www.veleri.hr/ }\end{array}$ & $\begin{array}{c}\text { Occupational Safety program } \\
\text { module - Fire Protection, } \\
\text { Professional studies, } \\
\text { Bachelor, (180 ETCS) }\end{array}$ & $\begin{array}{l}\text { Occupational Safety program } \\
\text { module - Fire Protection, } \\
\text { Professional studies, } \\
\text { Specialist, (120 ETCS) }\end{array}$ \\
\hline 4 & $\begin{array}{c}\text { Serbia, Novi Sad } \\
\text { University of Novi Sad, Faculty of } \\
\text { Technical Sciences, } \\
\text { http://www.ftn.uns.ac.rs/ }\end{array}$ & $\begin{array}{c}\text { Disaster and Fire } \\
\text { Risk Management } \\
\text { Academic studies, Bachelor, } \\
\text { (240 ETCS) }\end{array}$ & $\begin{array}{l}\text { Disaster and Fire } \\
\text { Risk Management, } \\
\text { Academic studies, } \\
\text { Master (60 ETCS) }\end{array}$ \\
\hline 5 & $\begin{array}{c}\text { Serbia, Niš } \\
\text { University of Nis, } \\
\text { Faculty of Occupational Safety, } \\
\text { http://www.ni.ac.rs/ }\end{array}$ & $\mathrm{n} / \mathrm{a}$ & $\begin{array}{l}\text { Occupational safety } \\
\text { - Fire Protection, } \\
\text { Academic studies, } \\
\text { Master (60 ETCS) }\end{array}$ \\
\hline 6 & $\begin{array}{c}\text { Serbia, Niš } \\
\text { University of Nis, } \\
\text { Faculty of Occupational Safety, } \\
\text { http://www.ni.ac.rs/ }\end{array}$ & $\mathrm{n} / \mathrm{a}$ & $\begin{array}{l}\text { Environmental Protection Eng. } \\
\text { - Emergency Management, } \\
\text { Academic studies, } \\
\text { Master (60 ETCS) }\end{array}$ \\
\hline
\end{tabular}




\begin{tabular}{|c|c|c|c|}
\hline 7 & $\begin{array}{c}\text { Serbia, Zemun, } \\
\text { Higher Engineering School of } \\
\text { Professional Studies, } \\
\text { http://www.tehnikum.edu.rs/ }\end{array}$ & $\begin{array}{c}\text { Occupational safety } \\
\text { - Fire Protection and Rescue, } \\
\text { Professional studies, } \\
\text { Bachelor, (180 ETCS) }\end{array}$ & $\begin{array}{c}\text { Occupational safety } \\
\text { - Fire Protection and Rescue, } \\
\text { Professional studies, } \\
\text { Specialist, (60 ETCS) }\end{array}$ \\
\hline 8 & $\begin{array}{c}\text { Serbia, Novi Sad, } \\
\text { Higher Technical School of } \\
\text { Professional Studies in Novi Sad } \\
\text { http://vtsns.edu.rs/ }\end{array}$ & $\begin{array}{c}\text { Occupational Safety - } \\
\text { Fire Protection, Professional studies, } \\
\text { Bachelor, (180 ETCS), } \\
\text { Also available as on-line studies }\end{array}$ & \multirow{2}{*}{$\begin{array}{l}\text { Environmental Protection Eng. } \\
\text { - Fire Protection and Rescue in } \\
\text { Emergency Situations, } \\
\text { Professional studies, } \\
\text { Specialist, (60 ETCS) }\end{array}$} \\
\hline 9 & $\begin{array}{c}\text { Serbia, Novi Sad, } \\
\text { Higher Technical School of } \\
\text { Professional Studies in Novi Sad } \\
\text { http://vtsns.edu.rs/ }\end{array}$ & $\begin{array}{l}\text { Environmental protection Eng. } \\
\text { - Civil Protection and Rescue in } \\
\text { Emergency Situations, } \\
\text { Professional studies, } \\
\text { Bachelor, (180 ETCS) }\end{array}$ & \\
\hline 10 & $\begin{array}{l}\text { Serbia, Zvečan, } \\
\text { Higher Technical School } \\
\text { of Professional Studies, } \\
\text { http://vts-zvecan.edu.rs/ }\end{array}$ & $\begin{array}{l}\text { Occupational safety } \\
\text { - Fire Protection, } \\
\text { Professional studies, } \\
\text { Bachelor, (180 ETCS) }\end{array}$ & $\begin{array}{l}\text { Occupational safety } \\
\text { - Fire Protection, } \\
\text { Professional studies, } \\
\text { Specialist, (60 ETCS) }\end{array}$ \\
\hline
\end{tabular}

Study programs curricula are different, but subjects' common ground is that they are dedicated to teaching the students to deal with the consequences, instead the disaster and fire prevention. The majority of programs are in fire protection field, and there is a lack of subjects treating fire risks theory and fire safety issues. Preventive measures are treated only as prescriptive ones; although contemporary fire safety engineering is about performance based measures, risk theory and engineering judgment. Very few programs are in the emergency situations or civil protection field. The lack of disaster risk management basic terminology in Balkan languages is obvious; we do not have the adequate terms for disasters, hazards, vulnerability, resilience, etc., in the programs' or subjects' curricula.

Even though the Fire Protection and Civil Protection studies were established long before Environmental Protection, in Serbia, there is no Fire Protection scientific field in Technical Sciences (since 2006.), nowadays it is only a branch of Environmental Protection and Occupational Safety scientific field. There is a similar situation in Croatia, as well. At University of Zagreb there is Fire Engineering - academic postgraduate specialist study ( http://pi.grad.hr/). The study program is in the Civil Engineering field.

Only one study program was found in Bosnia and Herzegovina: Civil Protection academic bachelor program at Independent University of Banja Luka, Faculty for Safety and Protection.

There are no higher education study programs in the field of Disaster Risk Management and Fire Safety Engineering in Montenegro, Albania, nor in FYR Macedonia.

According to the latest enrolment data of Higher Education Institutions in Serbia and Croatia (Table 1), there was approximately 390 spots for the $1^{\text {st }}$ level - bachelor students, and only 230 spots for the $2^{\text {nd }}$ level - specialist professional or academic master students.

There is one master academic program in University of Novi Sad (since 2011), and two master programs in University of Niš. Master professional will be established this year in Higher Technical School of Professional Studies in Novi Sad. There is an insufficient number of master degree programs in Balkan region to ensure sustainable and uniform capacity building in human resources in this area, and academic bachelor studies are implemented only at UNS, Faculty of Technical Sciences. A similar program does not exist even in neighbouring European countries, and moreover, the current situation in higher education in this field is not self-sustainable, because there are no doctoral programs to ensure future university professors and research. Existing higher education programs do not meet the needs of Serbia or Croatia for qualified staff, neither meet the needs of the region in its entirety. It is necessary to build countries' own, consistent and compatible capacities in higher education in this area in the Balkans, which will enable a uniform level of required knowledge and skills, as well as recognition of qualifications and supporting studying and working mobility in the region. 
The brief analysis of available master and doctoral study programs in higher education institutions (HEIs) in the field of Disaster Risk Management and Fire Safety Engineering was done on the European level (Laban et al. 2015). It was found that the majority of the most advanced engineering study programs in this field are available at Lund University - LU (Sweden), Danish Technical University - DTU (Denmark), University of Edinburgh - UE (Great Britain) and Ss. Cyril and Methodius University in Skopje - UKIM (FYR Macedonia), and all of the studies are established in a close connection to Faculties/Departments for Civil Engineering. There are also fully developed study programs, at all three Bologna levels, at Faculty of Special Engineering, University of Žilina (Slovak Republic).

Cooperation with the European HEIs and their contribution is crucial for new programs quality: knowledge sharing, experience transfer in the fields of scientific research and education, particularly in developing similar programs and modules and assistance in defining needs for program content and teaching methods improvement and modern ICT and computer technology use in the education process coinciding with higher education development in the EU.

Specific master programs, that are available in other European countries' HEIs, indicate complementary strong and wide competences:

- DTU: Master in Fire Safety (research areas: Fire Behaviour, People Safety, Structural Safety, Civil Engineering Risk and Decision Analysis); $\mathrm{PhD}$ studies in research areas (http://www.dtu.dk/);

- LU: MSc studies: Risk Management and Safety Engineering, Disaster Risk Management and Climate Change Adaptation, Fire Safety Engineering - international, Human Factors and System Safety - online; PhD studies: Systems Safety (http://www.lunduniversity.lu.se/);

- UE: MSc studies: Structural and Fire Safety Engineering, Fire Safety Engineering international, $\mathrm{PhD}$ studies in research areas (http://www.ed.ac.uk/);

- UNIZA: MSc studies: Security Management, Critical Infrastructure Protection, Crisis Management, Rescue Services; PhD studies: Security Management, Crisis Management, Rescue Services (http://www.lunduniversity.lu.se/);

- UKIM: PhD studies: Earthquake engineering, Research areas: Natural and Technological Hazards, Risk, Disaster Management and Strategic Planning, PhD studies in research areas (http://www.ukim.edu.mk/).

\section{COMMON REGIONAL NEEDS BRIEF ANALISYS}

The role of Balkan's HEIs is crucial for harmonizing the new programs content with the Region's needs: assessing the level and quality of HEIs resources in this field and identifying the key competences, knowledge and skills necessary for contemporary practice and future needs.

Other civil associations' contribution in regional needs analysis is crucial for the specific expertise identifying the current state of practices: the quality of knowledge and skills of active experts working in enterprises and institutions in field of Disaster Risk Management and Fire Safety (e.g. National Fire Protection Association, Fire-fighters and Rescue Associations, Voluntary Firefighters' Associations, Chamber of Engineers, Chambers of Commerce and Industry, etc.). National associations, but also regionally oriented ones, represent a wide platform for gathering of experts dealing with emergency situations and fire safety.

Youth organisations (e.g. National Committees of European Youth Parliament, Students' Associations, etc.) have crucial role in the specific expertise - the youth inclusion in the development of safety and resilient society and their opinion concerning the state of awareness about disaster and fire risks. The safety culture among youth would develop the need for higher education in this area, as well as the mechanisms of regional cooperation in Disaster Risk Management and Fire Safety Engineering (DRM \& FSE) area. European Youth Parliament national committees in our region already have good cooperation and working procedures replicated from EU parliament. Their example of good practise could be replicated in other cooperation activities among youth associations. 
Common regional needs to improve the resilience of the region to hazards are recognized. The first of all is a need for human resources - experts, who are competent to operate in prevention, reaction and recovery phases of the catastrophic events and solve engineering problems in the field of DRM $\&$ FSE. The second is a need to ensure competitive experts who are able to create a sustainable financial plan for disaster preparedness and preventive measures, according to regional economy recourses.

The overall broader objective that capacity building in higher education will contribute is to build a sustainable educational foundation in DRM \& FSE field in the Balkans, and ensure national professional resources and regional capacity for resilient society. Issues related to disaster and fire risk management, and risk modeling are of particular importance, as they form the basis of a comprehensive understanding of cost and benefits of adequate national or international programs aiming at reducing the risk of disasters and fires. Strengthen regional cooperation in education and research will also support capability of regional cooperation and interoperability in hazardous events.

There are needs to modernize or develop curricula, and to implement the programs in national languages and in English, as well.

\section{THE BASICS OF COMMON REGIONAL STUDY PROGRAM PROPOSAL}

The subject area, Disaster Risk Management and Fire Safety Engineering, refers to Multidisciplinary / Interdisciplinary disciplines, with Engineering and engineering trades as the dominant academic discipline, while other disciplines addressed by curricula being Environmental protection, Architecture and Construction, Civil Protection, Fire Science, Climatology, Hydrology, Seismology and Economy.

These programs should foster the assessment of transversal skills. The implementation of interdisciplinary study programs DRM \& FSE in the field of Technical Sciences, created in a way that enables continuation of the studies for a number of different profiles of engineering professions, also enables continuation of the studies of active professional experts. Also, supporting the production and adoption of Open Educational Resources in diverse European languages, enables sharing of good practise and joint research activities in the region. Study programs should be available in English and regional languages as well as a Glossary of DRM \& FSE key words and terms and DRM \& FSE On-line Library.

Educational ICT based laboratories should be created in Balkan's HEIs with interoperability capabilities and the On-line library should provide international and regional case-study and research publications. That insures common regional problem approach and knowledge compatibility also in accordance to contemporary trends in field of DRM \& FSE.

Modernisation, accessibility and internationalisation of the higher education field in Balkan Countries should be supported through the innovative DRM \& FSE master and doctoral study programs in HEIs, which will provide experts with recognizable competences and profiles of professionals at the labour market and EQF, capable to meet various requirements of regional needs. An interdisciplinary, multi-language and ICT based education approach insures regional cooperation, allows the exchange of knowledge and the mobility of students, teachers and workers, and strengthens national and regional capacities in EU integrations.

Faculties/Departments of Civil Engineering in our region could successfully develop the new study programs and interdisciplinary research area, because bought disasters and fires are happening in built environment, and their impact on human lives is in proportion to urban environment's and buildings' security and safety in case of earthquakes, fires, landslides, floods, hurricane winds, etc.

Specific subject curriculum should be dedicated to the vulnerable social groups' safety (disabled people, hospitalised persons, poor people living in slums, the homeless, elderly people and children). EU law and technical standards should also be the topic of specific subject curriculums.

Acquired knowledge in the field of Disaster Risk Management and Fire Safety Engineering provides the base for building a resilient society. 
Target groups, who could be interested in this type of education, are: students of academic and professional studies in other technical fields, young engineering professionals (age 27 - 40) within the institutions and companies, future engineering executives in disaster risk management and fire safety, unemployed persons interested in career path in DRM \& FSE areas, and professors and teaching assistants from colleges and universities of technical sciences.

European cooperation is needed for the assistance in program modernization, development and implementation, through knowledge sharing, experience transfer in the fields of scientific research and education, particularly in developing similar programs and modules, and assistance in defining needs for program content and teaching methods improvement as well as modern ICT use in the education process coinciding with higher education development in the EU.

\section{CONCLUSIONS}

Numerous human casualties, significant material damage and negative environmental impact of natural and manmade disasters and fires in the Balkans are the warning calling for change of approach to these issues.

Resilient societies are based on knowledge and training, as well as preparedness. Building synchronized regional capacities in higher education in Disaster Risk Management and Fire Safety Engineering, according to regional needs and contemporary trends, is a first step towards building resiliency of our region.

\section{ACKNOWLEDGMENTS}

The work reported in this paper is a part of the investigation within the research project „Development and aplication of contemporary procedures for design, construction and maintance of buildings“" supported by the Department for Civil Engineering and Geodesy, Faculty of Technical Sciences in Novi Sad. This support is gratefully acknowledged.

\section{REFERENCES}

Laban M., Popov S., Radonjanin V., Milanko V., Frank A., Vukoslavčević S., 2015. Knowledge FOr Resilient society / K-FORCE, Erasmus+ Project proposal submission, Call for proposal EAC/A04/2014 KA2 - Cooperation for innovation and the exchange of good practise - Capacity Building in the field of Higher Education 